\title{
Práticas psicológicas em instituição: atenção, desconstrução e invenção
}

\author{
Apresentação
}

$\mathrm{A}$ idéia de publicar o dossiê Práticas psicológicas em instituição: atenção, desconstrução e invenção surgiu durante o IX Simpósio da ANPEPP, em Águas de Lindóia, São Paulo, no ano de 2002. Naquele momento, nosso grupo de trabalho constatava a necessidade de não só levar adiante as idéias que norteiam as pesquisas desenvolvidas pelos seus membros, mas também de divulgá-las de forma mais ampla. Para isso, solicitamos ao então editor da revista Estudos de Psicologia, Oswaldo Yamamoto, um espaço para publicação dos nossos trabalhos e que agora se concretiza neste dossiê.

Esse grupo de trabalho (GT) tem uma história de dez anos na ANPEPP. Reunido pela primeira vez em 1994, abordando a temática Problematização das relações entre teoria e prática em Psicologia Clínica, o GT assumiu novas configurações em termos de composição, ao longo dos últimos anos. Embora tendo surgido no âmbito da Psicologia Clínica, não se direciona exclusivamente para essa área de atuação. Os estudos ora desenvolvidos têm como idéia central o acolhimento ao sofrimento psíquico; e como eixo norteador atitudinal das práticas psicológicas em instituições, a atenção psicológica.

Tal direção aponta para o exercício de uma práxis psicológica nas instituições em que se apresente uma demanda de sofrimento que possa ser acolhida pelo profissional dessa área, por meio de ações que se caracterizam por uma atenção psicológica. Nesse sentido, os pesquisadores desse grupo questionam-se sobre as brechas que poderiam ser entrevistas pela promoção de tais práticas, visando que, efetivamente, possibilitem transformações tanto para o campo de atuação do psicólogo (e outros profissionais de saúde e educação), quanto para sua formação e oferecimento de melhoria de serviços com qualidade à comunidade. Partindo-se das condições do mundo e sociedade atuais, bem como do modo de ser e viver do homem contemporâneo em confronto com a tecnocracia científica, são investigadas quais possibilidades e desafios se impõem aos pesquisadores inquietos com a fragmentação e o desamparo sócio-ético-político da humanidade no mundo contemporâneo. Nos trabalhos apresentados neste dossiê, foi reconhecido esse percurso pelos temas dos participantes em seus programas de pós-graduação de origem. Tais temas mostram que uma outra atitude passa a ser demandada pelos pesquisadores imersos no tecido social que envolve suas práticas interventivas. Procura-se promover a abertura do imaginário, ou melhor, as brechas do humano entre atenção e hábito. Como resultado dessas preocupações, alguns temas compõem os eixos temáticos desse grupo, tais como: a explicitação do compromisso ético-político dessas práticas; o caráter dialógico-constitutivo dessas práticas na relação com a população atendida; a análise crítica de políticas públicas em saúde e educação; e formas de investigação participativa interventiva e questionamento metodológico, entre outros.

Não restam dúvidas de que todo esse processo de reformulações teórico-metodológicas que marca o GT-28 expressa reflexões sobre a prática clínica psicológica do modo como esta vem se desenvolvendo em nosso país, nos contextos científicos e profissionais, desde o momento em que a Psicologia se instituiu oficialmente no Brasil, há quarenta anos atrás. Tal forma de pensar as práticas psicológicas possibilitou reflexão investigativa acerca de implicações nos diversos encontros de prática psicológica em instituição em que não existe um saber dado, mas um conhecimento a ser produzido por aqueles envolvidos no processo. Recorrendo a situações as mais variadas da prática psicológica em instituições como contextos para elaboração de experiência, bem como sua repercussão na pesquisa, pós-graduação, extensão, foram contemplados espaços de responsabilidade para repensar a atuação do psicólogo frente às demandas sócio-culturais prementes do país. E desse modo, promovendo-se questionamentos sobre a necessidade de uma rede de serviços de atendimento de saúde mental para a população. É assim que, através da atenção à demanda e da desconstrução do constructo teórico estrito, práticas psicológicas em instituições têm surgido e podem constituir-se como invenções que reconduzem não somente ao fazer clínico do psicólogo, como também resgatam a investigação de um saber e conhecimento mais condizentes com a experiência do homem no mundo.

Partimos da atenção psicológica, como intervenção para o acolhimento do sofrimento humano em situações de crise, a fim de compreender sua eficácia terapêutica ao desamparo e estabelecer as bases conceituais para uma intervenção clínica socialmente contextualizada e engendrada a partir do encontro intersubjetivo criado pelas práticas psicológicas em instituição. Esse grupo de trabalho e seus componentes exploram, ainda, possibilidades de um campo clínico social interdisciplinar e o questionamento de formas de reificação e 
exclusão, prevalecentes nas políticas públicas de saúde e educação. Assim concebida, a atenção psicológica passa a atender a uma demanda no campo do saber-fazer da Psicologia Clínica, ao solicitar do psicólogo e, consequientemente, da sua formação, um olhar mais crítico e comprometido com as dimensões históricas, sociais e culturais presentes no sofrimento humano e no processo de subjetivação.

Os artigos deste dossiê refletem o pensamento que perpassa esse grupo, formado por pesquisadores de várias instituições, cada um com as suas formas singulares de pensar e fazer psicologia, porém unidos em torno das preocupações que caracterizam o grupo. É preciso lembrar que, para atender a limites editoriais da revista, nem todos os pesquisadores do grupo puderam participar do dossiê; tivemos de utilizar critérios internos para seleção do material que está sendo publicado. Para esta apresentação, recorremos ao material elaborado pela coordenadora do GT-28 Práticas psicológicas em instituição: atenção, desconstrução e invenção, Henriette Tognetti Penha Morato, a quem agradecemos pela grande colaboração nesta apresentação, ao favorecer a explicitação das idéias e evolução histórica do grupo, do qual ela é uma das fundadoras.

É extremamente gratificante, neste momento, poder ver a publicação do nosso dossiê. Trabalhar nesta edição, além de ter representado uma experiência de grande responsabilidade, nos deu a certeza do caminho trilhado e do muito a ser ainda percorrido. Esperamos que o objetivo maior da produção acadêmica e científica esteja sendo alcançado por todos nós que constituímos esse grupo. A troca de idéias, a convivência com os diferentes olhares sobre a Psicologia e, sobretudo, o respeito às diferenças advindas de modos de ser e de pensar a prática psicológica nas suas especificidades é o que esperamos sejam exercitados. Estaremos confortáveis, satisfeitos e, acima de tudo, recompensados, se esse material puder acrescentar e contribuir para um saber-fazer, no campo da psicologia, mais comprometido com a realidade brasileira e com a condição subjetiva do homem no mundo.

Profa. Dra. Elza Dutra/UFRN Editora Convidada 